\title{
Kompatibilitas sambung mikro Cinchona ledgeriana dengan C. succirubra berdasarkan anatomi dan elektroforesis SDS- PAGE protein daerah pertautan
}

\author{
Compatibility of micrografting Chincona ledgeriana and $C$. succirubra based \\ on anatomy and SDS-PAGE protein electrophoresis of union area \\ Nurita TORUAN-MATHIUS ${ }^{1)}$, LUKMAN ${ }^{2)}$ \& AGUS - PURWITO ${ }^{3)}$ \\ 1) SEAMEO BIOTROP, Bogor, Indonesia \\ ${ }^{2)}$ Fakultas Pertanian, Universitas Malikussaleh, Nagroe Aceh Darusalam, Indonesia \\ ${ }^{3)}$ Fakultas Pertanian, Institut Pertanian Bogor, Bogor, Indonesia
}

\begin{abstract}
Summary
Rootstocks and scions interaction causes different responses within individuals of scion from the same clone. The objectives of this research were to determine compatible and uncompatible combinations of micrografting between Cinchona succirubra $A$, and C. succirubra $B$ with C. ledgeriana $Q R C 205$ and Cib5 clones, based on anatomy structure and SDS-PAGE protein bands pattern of stem at union area between rootstock and scion. The research was arranged in a Completely Randomized Design, with rootstock/scion combinations CSA/QRC205, CSA/Cib5, CSB/QRC205, CSB/Cib5 and as a controls were the combination of CSA/CSA, CSB/CSB, ORC205/QRC205, Cib5/Cib5, succi and ledger seedlings with the same age. Effect of rootstocks on scion was studied based on anatomy structure of the union area between rootsocks and scions and SDS-PAGE protein bands pattern. The results showed that the union of stem between rootstocks and scion was initiated by callus formation, cells differentiation and the vascular vessels formation. The anatomy of stem union area of CSA/QRC205 as a compatible combination of rootsotck and scion was the same as unmicrografted plantlet. At uncompatible combination CSB/Cib5 showed the formation
\end{abstract}

of stone cells as a line along stem cyrcle at union area and heavely callus formation at outside of rootstock and scion stems. SDSPAGE protein bands pattern from the compatible combination was the same as planlet control. On the otherhand, from the uncompatible combinations CSB/Cib5 were found protein degradation and the formation of new proteins with molecular weight 21 and 30 $k D$.

[Key words: In-vitro micrografting, rootstock, scions, electrophoresis, SDSPAGE protein, stem anatomy].

\section{Ringkasan}

Interaksi batang bawah dengan batang atas menimbulkan berbagai keragaman respons antar individu batang atas dari klon yang sama. Tujuan penelitian ini adalah untuk menetapkan kombinasi yang kompatibel dengan yang tidak kompatibel antara kina klon Cinchona succirubra A, dan C. succirubra B dengan $C$. ledgeriana klon QRC205 dan Cib5, berdasarkan anatomi dan pola pita SDS-PAGE protein daerah pertautan antara batang atas dengan batang bawah. Percobaan disusun dengan Rancangan Acak Lengkap kombinasi yang diuji adalah CSA/QRC205, 
CSA/Cib5, CSB/QRC205, CSB/Cib5 dengan kombinasi kontrol CSA/CSA, CSB/CSB, QRC205/QRC205, Cib5/Cib5, tanaman kina succi dan ledger tanpa sambungan dengan umur yang sama. Pengamatan dilakukan terhadap struktur anatomi daerah pertautan antar batang bawah dengan batang atas dan pola pita protein SDS-PAGE batang atas. Hasil yang diperoleh menunjukkan bahwa tahapan pemulihan daerah pertautan penyambungan batang bawah dengan batang atas diawali dengan pembentukan kalus, diferensiasi sel dan terbentuknya jaringan ikatan pembuluh gabungan. Kombinasi antar batang bawah dengan batang atas yang kompatibel yaitu CSA/QRC205 memperlihatkan struktur anatomi daerah pertautan yang serupa dengan struktur anatomi batang planlet yang tidak disambung. Pada kombinasi yang tidak kompatibel yaitu CSB/Cib5 pada daerah pertautan terbentuk sel-sel batu berbentuk garis yang memanjang di tengah lingkaran batang. Di samping itu pada daerah pertautan terbentuk kalus yang berlebih ke arah luar baik pada batang atas maupun batang bawah. Pada kombinasi yang kompatibel pola pita protein sama dengan planlet kontrol. Pada kombinasi yang tidak kompatibel yaitu kombinasi $\mathrm{CSB} / \mathrm{Cib} 5$ terjadi degradasi protein dan pembentukan protein baru dengan berat molekul sekitar 21 dan $30 \mathrm{kD}$.

\section{Pendahuluan}

Struktur anatomi daerah pertautan jaringan ikatan pembuluh batang bawah dengan batang atas yang harmonis menyebabkan translokasi air dan hara mineral dari akar ke bagian atas planlet dan translokasi fotosintat dari bagian atas planlet ke akar dapat berjalan dengan baik. Sobhana et al. (2001) menyatakan bahwa interaksi batang bawah dengan batang atas yang baik dapat mempercepat laju pertumbuhan planlet. Pada kombinasi batang bawah dan batang atas yang kompatibel menyebabkan proses metabolisme planlet dapat berlangsung dengan baik. Sebaliknya pada kombinasi yang tidak kompatibel proses metabolisme planlet menjadi terganggu dan mengakibatkan pertumbuhan planlet terhambat.

Ji-Zhong et al. (2002) menjelaskan bahwa pada daerah pertautan antara batang bawah dengan batang atas yang tidak sesuai, dapat meningkatkan aktivitas enzim peroksidase (POD) dan isoperoksidase (IOD) sehingga dapat mendegradasikan auksin yang ditranslokasikan dari pucuk ke akar. Madjid (1974) mengemukakan bahwa pada okulasi tanaman karet yang tidak kompatibel dapat menurunkan produksi lateks sampai $40 \%$. ToruanMathius et al. (1999) juga menyatakan bahwa pada okulasi tanaman karet yang tidak kompatibel terdapat penyempitan kulit kayu dengan ketebalan kulit batang bawah yang lebih besar, serta meningkatnya jumlah sel parenkim dan sel batu pada daerah pertautan sampai ke bagian kulit kayu lunak.

Raghothama (1999) menyatakan bahwa pada planlet Arabidopsis sambungan yang kompatibel hubungan timbal balik (source dan sink) antara batang bawah dan batang atas terjadi secara normal. Errea et al. (2001) menjelaskan pada sambung mikro Apricot kombinasi yang tidak kompatibel terdapat kulit yang menebal dan keras. Prawoto et al. (1987) menemukan adanya perbedaan anatomi kulit batang pada daerah pertautan antara penyambungan yang kompatibel dengan yang tidak kompatibel pada planlet kakao, penyambungan yang tidak kompatibel ditunjukkan dengan banyaknya akumulasi lignin pada daerah pertautan.

Warmund et al. (1993) menjelaskan penyambungan yang tidak kompatibel pada planlet apel dapat membentuk kulit 
Kompatibilitas sambung mikro Cinchona ledgeriana dengan C. succirubra berdasarkan...

kayu yang tidak mulus pada pergantian pembuluh xilem oleh jaringan parenkim. Toruan-Mathius et al. (1999) melaporkan bahwa pada penyambungan tanaman karet kombinasi PB260/PR255 dan PB260/ PR300 yang tidak kompatibel, terdapat anatomi kulit batang daerah pertautan yang tidak mulus, dan terbentuk sel batu yang lebih banyak. Mikrografting pada jeruk mandarin, kombinasi yang kompatibel menunjukkan pertumbuhan planlet lebih vigor dan kualitas buah menjadi lebih baik.

Analisis pola pita protein hasil elektroforesis SDS-PAGE protein telah digunakan untuk mengidentifikasi ketidak sesuaian pada okulasi tanaman karet (Lizawati et al., 2002; Toruan-Mathius et al., 1999). Ketidak sesuaian antara batang bawah dan batang atas menyebabkan timbulnya reaksi yang negatif menyebabkan terganggunya proses metabolisme antara lain terjadinya degradasi protein atau timbulnya protein yang baru (Lizawati et al., 2002). Toruan-Mathius et al. (2002) menyatakan bahwa heterogenitas batang bawah pada sistem okulasi Hevea brasiliensis dapat dapat menimbulkan berbagai tingkat keragaman respons antar individu batang atas dari klon yang sama.

Lasminingsih et al. (1989) melaporkan bahwa dari elektroforesis serum lateks yang dielektroforesiskan pada gel akrilamid terdapat enam kelompok pola pita protein dari 36 klon karet. Lizawati et al. (2002) melaporkan berdasarkan hasil SDS-PAGE protein lateks kombinasi okulasi dari 24 klon yang diuji terbagi menjadi dua kelompok yang terpisah pada koefisien keragaman 58\%, umumnya batang bawah yang sama berada pada satu kelompok kecuali BPM24/RRIC101 dan
BPM1/REIC100 karena adanya pengaruh batang bawah klon RRIC110 yang cukup kuat terhadap batang atas klon RRIC100 yang menyebabkan terjadinya degradasi protein.

Monero et al. (1994) melaporkan bahwa pada penyambungan peach dan pulm yang tidak kompatibel dapat menyebabkan penurunan kandungan protein dan asam amino pada seluruh organ planlet. Toruan-Mathius et al. (1999 dan 2000) menemukan bahwa batang atas PB260 yang diokulasikan pada berbagai klon batang bawah menyebabkan polimorfisme pita protein lateks batang atas dan terbentuknya protein baru dengan berat molekul 20-25 kDa. Agbaria et al. (1997) melaporkan terbentuknya protein baru yang disebut Heat Shock Protein (HSP) pada daun bunga mawar kultivar jenis batang bawah. Agbaria et al. (1998) juga menemukan bahwa penyambungan mempengaruhi aktivitas enzim untuk pembungaan pada bunga ros yaitu nitrat reduktase dan glutamin sintetase dalam daun.

Tujuan penelitian ini adalah untuk mengetahui struktur anatomi daerah pertautan antara batang bawah dengan batang atas, pola pita protein daun batang atas. Serta untuk mengetahui kombinasi klon $C$. succirubra $A$, dan $C$. succirubra dengan $C$. ledgeriana klon QRC205 dan Cib5 hasil sambung mikro yang kompatibel.

\section{Bahan dan Metode}

Bahan yang digunakan dalam percobaan ini adalah planlet kina $C$. succirubra (CSA dan CSB) dan C.ledgeriana QRC205 dan Cib5 yang dikulturkan dalam medium Murashige\& Skoog (1962). 
Toruan-Mathius et al.

Kombinasi sambung mikro batang bawah dan batang atas yang diuji adalah CSA/ QRC205-V, CSB/ QRC205-V, CSA/Cib5$\mathrm{V}$, CSB/Cib5-V dengan kombinasi kontrol CSA/CSA, CSB/CSB, QRC205/QRC205, Cib5/Cib5, tanaman kina succi dan ledger tanpa sambungan berumur tiga bulan dengan umur yang sama. Masing-masing per-lakuan diulang sebanyak lima kali. Pemilihan contoh untuk analisis anatomi dan SDS-PAGE protein di dasarkan pada planlet yang pertumbuhannya terhambat.

Untuk mempelajari anatomi dan penetapkan kompatibilitas antar batang bawah dengan batang atas, dibuat sediaan anatomi penampang melintang dan membujur daerah pertautan dari masingmasing perlakuan menurut metode Sass (1958). Ketebalan irisan sediaan anatomi adalah $5 \mu \mathrm{m}$. Pengamatan anatomi daerah pertautan hasil mikrografting dilakukan dengan cara mempelajari struktur anatomi daerah pertautan meliputi jaringan kambium, pembuluh kayu (xilem) dan pembuluh kulit kayu (floem) selanjutnya dibandingkan dengan anatomi batang yang tidak dilakukan sambung mikro. Pengamatan anatomi dilakukan pada saat planlet berumur delapan minggu setelah penyambungan, sedang dokumentasi hasil yang diperoleh menggunakan kamera Nikon yang dihubungkan dengan mikroskop Nikon pada pembesaran 40x.

\section{Elektroforesis SDS-PAGE protein}

Pengerjaan contoh dengan SDSPAGE mencakup ekstraksi protein, analisis kandungan protein, dan elektroforesis. Sebanyak 0,3 g daun kina hasil sambung mikro in vitro dimasukkan ke dalam lumpang porselin dan ditambahkan nitrogen cair, kemudian digerus sampai berbentuk tepung halus. Tepung halus selanjutnya dimasukkan ke dalam tabung Eppendorf yang berisi $1 \mathrm{~mL}$ larutan bufer ekstrak kemudian divortek dan disentrifugasi dengan kecepatan $1400 \mathrm{rpm}$ selama 20 menit. Supernatan ditampung dan endapannya dibuang. Protein daun yang sudah diperoleh kemudian disimpan dalam lemari pendingin pada suhu $0^{\circ} \mathrm{C}$ untuk digunakan dalam analisis selanjutnya.

Kadar protein ditetapkan menurut Lowry et al. (1951) yaitu sampel dari hasil ekstraksi protein dipipet sebanyak $20 \mu \mathrm{L}$ kemudian di masukkan ke tabung reaksi dan ditambahkan akuades $1,58 \mathrm{~mL}$, pereaksi C $600 \mathrm{~mL}$ kemudian dikocok dan didiamkan selama 10 menit kemudian menambahkan $200 \mu \mathrm{L}$ pereaksi D, lalu dikocok dan didiamkan 30 menit. Kadar protein di dalam larutan sampel diukur dengan spektrofotometer pada panjang gelombang $750 \mathrm{~nm}$. Kadar protein sampel dihitung berdasarkan kurva standar dengan persamaan regresi linear $\mathrm{y}=\mathrm{ax}+\mathrm{b}$.

Elektroforesis protein dilakukan dengan gel akrilamida menggunakan Sodium Dodecyl Suphate fat Polycrilamide Gel Elektroforesis (SDS-PAGE) (Leammli et al., 1970). Cetakan gel yang berisi $35 \mu \mathrm{L}$ contoh diletakkan pada alat elektroforesis yang bagian bawahnya telah diisi dengan penyangga elektroda yang diencerkan $1 / 10$ kalinya sampai $3 / 4$ bagian bejana dan bagian atas juga diisi dengan larutan penyangga elektroda. Sampel protein sebanyak $40 \mu \mathrm{L}$ di masukkan ke dalam sumur-sumur yang tercetak pada gel. Elektroforesis dijalankan dengan tegangan 110 volt selama 80 menit. Elektroforesis dihentikan apabila indikator mobilitas telah hampir mencapai ujung gel. Pewarnaan gel dilakukan menggunakan perak nitrat kemudian setelah pita-pita 
protein muncul pada gel, gel direndam dalam larutan fiksasi dan diawetkan dengan selopan. Pengaruh batang bawah dan batang atas dipelajari berdasarkan ada tidaknya pola pita protein yang dimiliki bersama berdasarkan berat molekul protein.

\section{Hasil dan Pembahasan}

Penampang melintang dan membujur hasil sambung mikro in vitro planlet kina dapat dilihat pada Gambar 1, 2 dan 3. Hasil yang diperoleh menunjukkan bahwa struktur anatomi batang planlet kina sama dengan struktur anatomi batang planlet berkayu dikotiledon lainnya, yaitu terdiri dari jaringan floem, kambium dan xilem. Jaringan kambium adalah jaringan yang berbentuk lingkaran yang membatasi antara jaringan floem dan xilem. Ke arah dalam kambium disebut xilem (pembuluh kayu) yang berfungsi untuk mengangkut air dan hara mineral dari akar ke atas, dan ke bagian luar kambium adalah floem (pembuluh kulit kayu) yang mengangkut hasil fotosintat dari bagian atas ke bawah tanaman.

Penampang melintang dan membujur planlet yang tidak disambung memperlihatkan sel yang masih utuh dimana antara satu dengan yang lain merupakan satu ikatan yang tidak terputus-putus baik pada jaringan floem, kambium dan xilem, hal ini terjadi karena struktur anatomi planlet tersebut masih merupakan satu individu (Gambar 1a dan 1b). Penampang melintang dan membujur daerah pertautan antara batang bawah dan batang atas hasil sambung mikro in vitro, yaitu kombinasi CSA/QRC205 menunjukkan bahwa kambium, xilem dan floem tidak berbentuk lingkaran yang utuh. Hal ini disebabkan adanya pemotongan berbentuk huruf $\mathrm{V}$ pada batang bawah dan batang atas. Pada daerah pertautan antara batang bawah dan batang atas tampak adanya sel-sel berukuran kecil, dengan sitoplasma sel yang penuh dalam jumlah cukup banyak. Selsel tersebut membentuk kalus yang tumbuh aktif.

Hartmann et al. (1997) menyatakan bahwa kalus adalah sekelompok sel parenkima yang berkembang di sekitar jaringan yang terluka. Produksi sel-sel parenkim merupakan langkah awal dari pembentukan kalus pada planlet yang terluka akibat penyambungan baik terhadap batang bawah ataupun terhadap batang atas. Sel-sel parenkima mampu membelah dan mempertahankan diri sampai menjadi sel dewasa. Perkembangan sel dan anatomi planlet akan berubah sejalan dengan perubahan waktu. Fungsi masing-masing jaringan/sel antara satu dengan lainnya berbeda-beda, jaringan yang belum terdiferensiasi berbeda fungsinya dengan jaringan yang sedang dan sudah berdiferensiasi. Kalus tersebut berdiferensiasi menjadi sel dewasa atau jaringan selanjutnya akan menjadi jaringan gabungan antara batang bawah dan batang atas baik berupa jaringan xilem gabungan, jaringan floem gabungan dan jaringan kambium gabungan.

Pertumbuhan kalus ini juga terjadi pada kombinasi CSB/QRC205 dan CSA/ Cib5 penampang melintang dan membujur (Gambar 2 a, b, c dan d) akan tetapi berbeda halnya dengan kombinasi $\mathrm{CSB} /$ Cib5 (Gambar 3). Perkembangan kalus menjadi sel dewasa atau jaringan pada sambung mikro planlet kina dapat terjadi pada saat planlet sudah berumur lima bulan setelah sambung mikro (pasca aklimatisasi). Struktur anatomi daerah pertautan pada umur tersebut sama dengan 
Toruan-Mathius et al.

(a) Penampang melintang Cross section

(b) Penampang membujur Longitudinally section

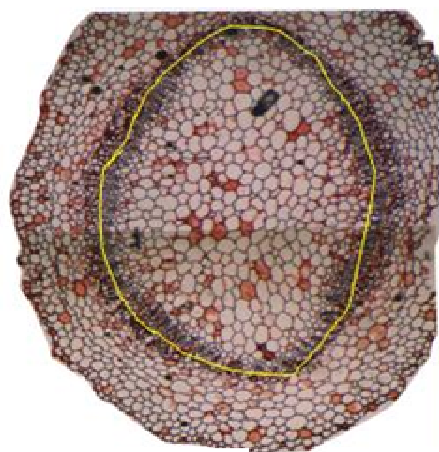

(c)

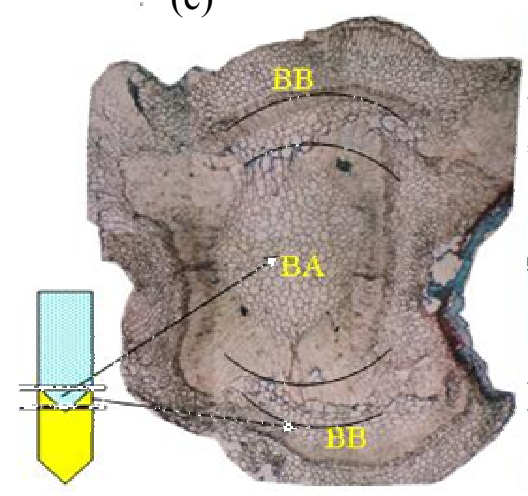

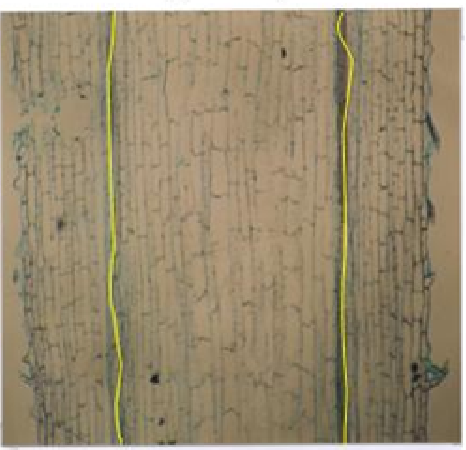

(d)

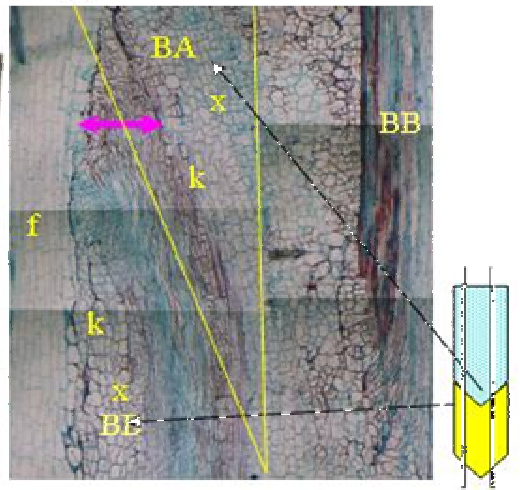

Gambar 1. Penampang melintang dan membujur batang daerah pertautan sambung mikro planlet kina umur delapan minggu setelah penyambungan. Dengan pembesaran 40x. f. floem, k. kambium, x. xilem, BB. batang bawah, dan BA. batang atas. (a) and (b) planlet tidak disambung, (c) dan (d) sambung mikro CSA/QRC205; $\rightarrow$ Daerah pertautan. Bars $=40 \mu \mathrm{m}$.

Figure 1. Cross and longitudinally sections union area micrografting of cinchona plantlet eight-week-old after micrografted. With $40 x$ magnification. f. phloem, $k$. cambium. x. xylem, BB. Rootstocks, and BA. Scion. (a) and (b) unmicrograft plantlet, (c) and (d) micrografting CSA/QRC205; $\rightarrow$ Union area. Bars $=40 \mu \mathrm{m}$. 
Kompatibilitas sambung mikro Cinchona ledgeriana dengan C. succirubra berdasarkan...

(a) Penampang melintang Cross section

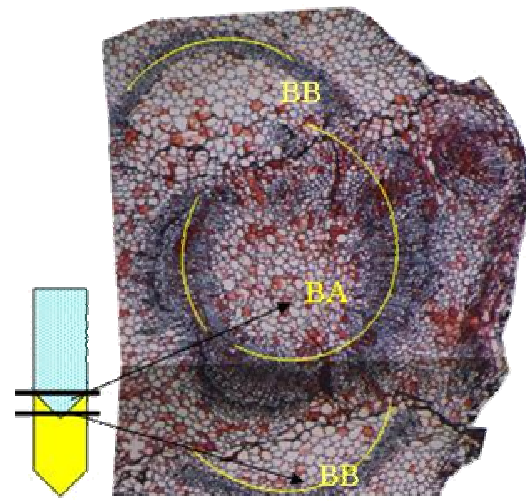

(c) (b) Penampang membujus Longindinal section

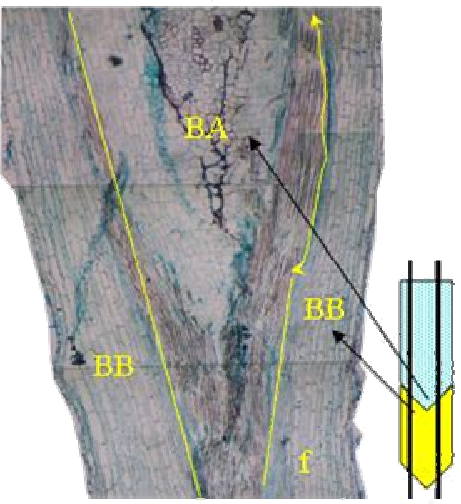

(d)
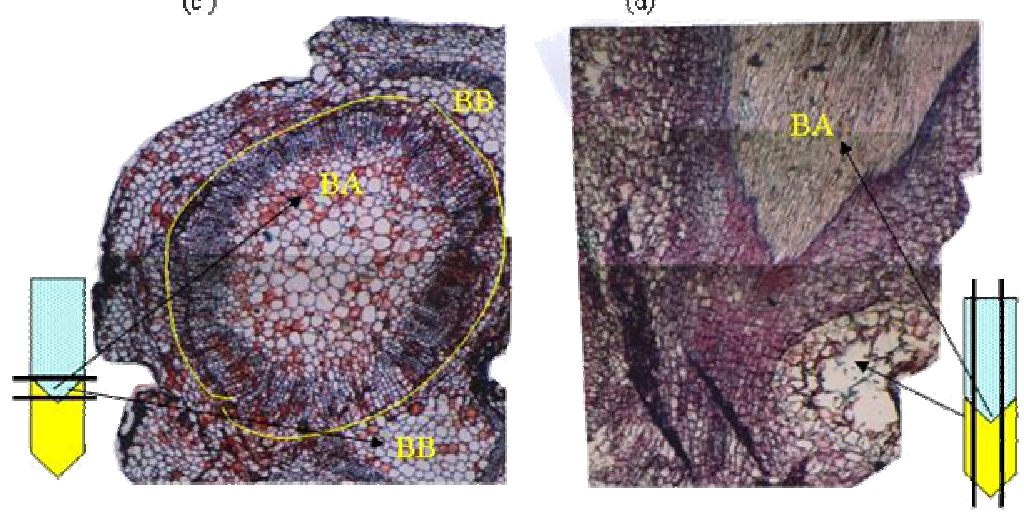

Gambar 2. Penampang melintang dan membujur daerah pertautan sambung mikro planlet kina umur delapan minggu setelah penyambungan. Dengan pembesaran 40x. BA. Batang atas, BB. Batang bawah, (a), (b). CSB/QRC205, (c) dan (d) CSA/Cib5; $\rightarrow$ Daerah pertautan. Bars $=40 \mu \mathrm{m}$.

Figure 2. Cross and longitudinally sections union area micrografting of cinchona plantlet eightweek-old after micrografted. With $40 x$ magnification. BA. Scion, BB. rootstocks, (a), (b). $C S B / Q R C 205$, (c) and (d) CSA/Cib5; $\rightarrow$ Union area. Bars $=40 \mu \mathrm{m}$. 
Toruan-Mathius et al.

(a) Penampang melintang Cross section

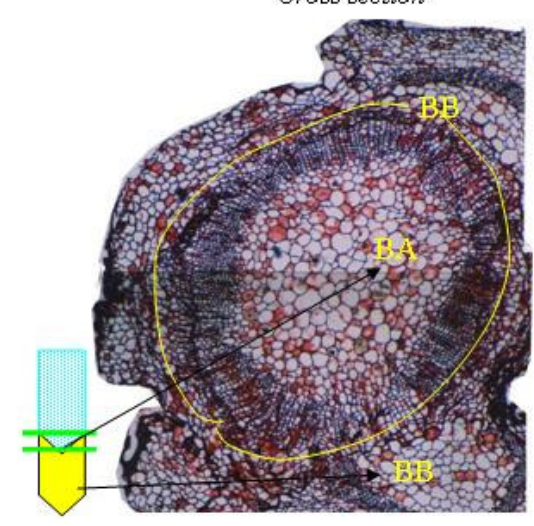

(c)

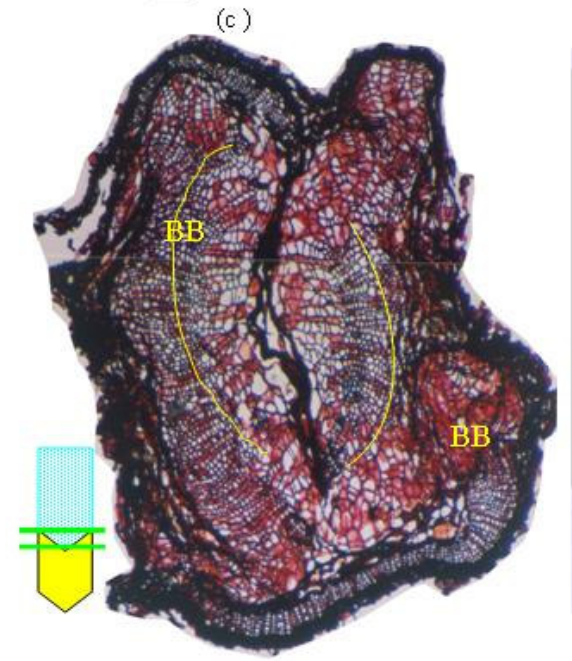

(b) Penampang membujur Longitudinally section

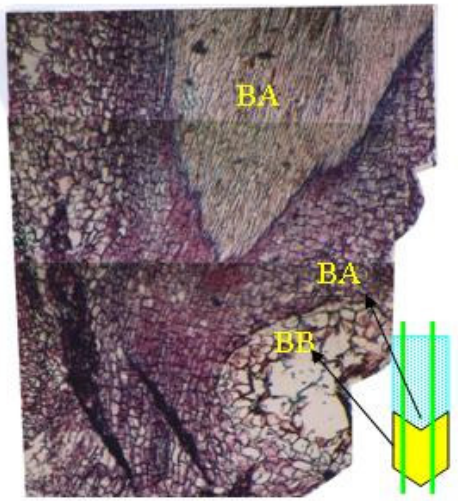

(d)

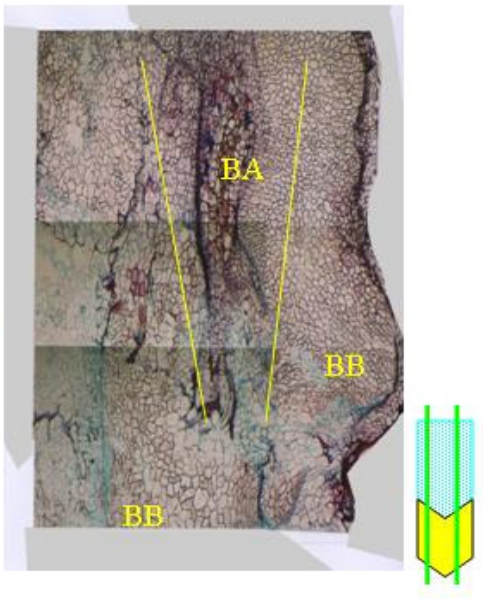

Gambar 3. Penampang melintang dan membujur planlet kina CSB/Cib5 umur delapan minggu setelah penyambungan. Dengan pembesaran 40x. BA. Batang atas, BB. Batang bawah. Bars $=40 \mu \mathrm{m}$.

Figure 3. Cross and longitudinally section stem plantlet of cinchona CSB/Cib5 eight-week after micrografted. With 40x magnification. BA. Scion, BB. Rootstocks. Bars $=40 \mu \mathrm{m}$. 
Kompatibilitas sambung mikro Cinchona ledgeriana dengan C. succirubra berdasarkan...

struktur anatomi batang planlet kina yang tidak disambung yaitu jaringan batang atas dapat menyatu lebih sempurna dengan jaringan batang bawah (Gambar 1). Pada daerah penyambungan tampak daerah irisan atau potongan bekas luka akibat sambung mikro (tanda panah Gambar 2). Hal ini sesuai dengan definisi kompatibilitas yaitu pertumbuhan planlet normal, tidak terjadi lignifikasi. Hal ini menyebabkan transportasi air, hara dan fotosintat berlangsung dengan baik.

Errea et al. (2001) menyatakan bahwa reaksi awal yang ditimbulkan pada sambung mikro adalah terjadinya proliferasi kalus pada daerah pertautan antara batang bawah dengan batang atas. Selanjutnya pada kombinasi yang kompatibel menghasilkan sambungan yang mulus dan pada kombinasi yang tidak kompatibel membentuk sambungan yang tidak normal misalnya kulit pada daerah pertautan lebih tebal dan lebih keras. Estrada-Luna et al. (2002) menjelaskan bahwa pada sambung mikro yang kompatibel pertumbuhan planlet tampak normal dan sambungan mulus sedang pada kombinasi yang tidak kompatibel planlet akan menjadi kerdil.

Xi \& Ding (1993) mengemukakan bahwa pada planlet walnut (Junglans regia) urutan penyembuhan hingga bertautnya jaringan pembuluh batang bawah dan batang atas meliputi mulai dari tidak berkalus, inisiasi kalus, pertemuan kalus batang bawah dengan kalus batang atas, diferensiasi kalus menjadi kambium, disusul pertautan kedua kambium, serta diferensiasi menjadi jaringan pembuluh dan pertautan antara keduanya. Rifa'i-Faiz (2003) menemukan sampai dengan waktu kurang dari tiga bulan pada sambung tanaman duku masih dalam perkembangan kalus. Tirtawinata (2003) melaporkan pada tanaman manggis yang sudah berumur tiga bulan setelah sambung, proses diferensiasi kalus menjadi kambium baru terjadi pada beberapa bagian yang berdekatan dengan lingkaran kambium batang bawah dan batang atas. Pada bagian sambungan yang lingkaran kambium batang bawah dan batang atas berjauhan diferensiasi kalus belum selesai pada sebagian besar sambungan. Richardson et al. (1996) melaporkan bahwa hasil mikrografting pada planlet apel, pertautan jaringan antara batang bawah dan batang atas terjadi pada hari ke 40 setelah perlakuan dan terus berlangsung hingga selesai dalam waktu enam bulan. Errea et al. (2001) juga menjelaskan perbedaan antara kombinasi yang kompatibel dengan yang tidak kompatibel akan terus meningkat sejalan dengan waktu yang berjalan.

Pada umur delapan minggu setelah sambung mikro kina dilakukan, sel kalus pada daerah penyambungan belum menjadi sel dewasa. Namun tampaknya translokasi fotosintat, air dan hara mineral pada planlet hasil mikrografting berlangsung dengan baik. Hal ini dapat terlihat dari pertumbuhan dan perkembangan planlet yang vigor. Berdasarkan hasil yang diperoleh pada kombinasi $\mathrm{CSB} / \mathrm{Cib} 5$ terdapat garis memanjang memotong tengah lingkaran batang (Gambar 3). Diduga garis tersebut merupakan bagian dari pembentukan xilem gabungan yang belum sempurna antara batang bawah dan batang atas karena belum dapat menunjukkan karakteristik yang khas sebagai xilem. Bentuk xilem yang masih samar dapat diduga akan membentuk sel batu, yang kemungkinan menghambat translokasi air dan hara mineral menuju ke tajuk atau translokasi fotosintat dari daun ke bagian bawah planlet menyebabkan pertumbuhan planlet menjadi terhambat. 


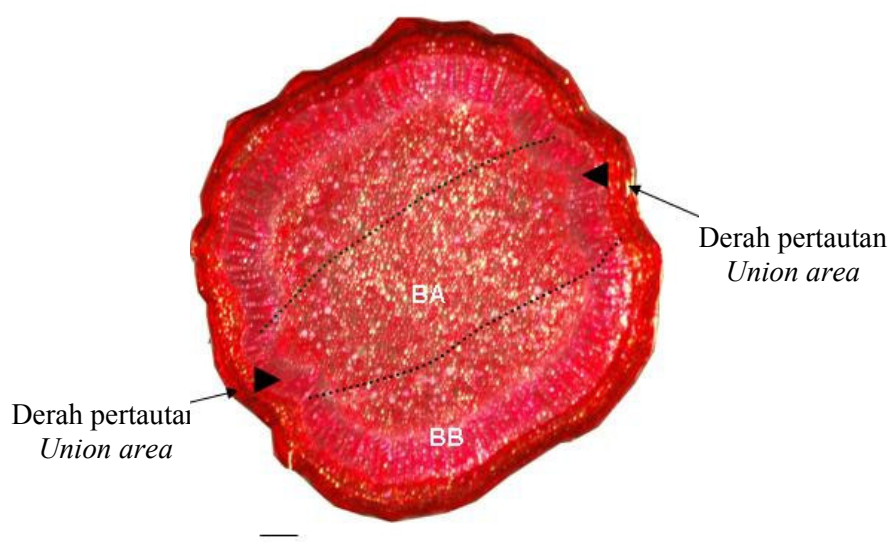

Gambar 4. Penampang melintang area pertautan sambung mikro batang planlet kina CS/CL umur lima bulan setelah sambung mikro in vitro dengan bentuk sambung tipe V. Bars $=40 \mu \mathrm{m}$.

Figure 4. Cross section of union area stem micrografed of cinchona plantlet CS/CL five-week after micrografted with type micrografted $V$. Bars $=40 \mu \mathrm{m}$.

\section{Elektroforesis protein}

Hasil elektroforesis protein kina daun batang atas kombinasi CSA/QRC205, CSB/QRC205, CSA/Cib5 dan CSB/Cib5 umur delapan minggu setelah sambung mikro dilakukan menunjukkan bahwa protein daun batang atas planlet kina dari klon yang diuji memiliki berat molekul 14 - $45 \mathrm{kD}$. Pada umumnya pola pita protein SDS-PAGE daun batang atas hasil sambung mikro sama dengan pola pita protein planlet kontrol, kecuali kombinasi CSB/Cib5. Pada kombinasi CSB/Cib5 terjadi degradasi dua pita protein pada berat molekul sekitar 21 dan $30 \mathrm{kD}$ (Gambar 5). Dapat disimpulkan bahwa pola pita protein hasil sambung mikro yang sama dengan kontrol disebut kombinasi yang kompatibel, dan kombinasi yang berbeda dengan kontrol disebut kombinasi yang tidak kompatibel. Tidak terbentuknya protein pada kombinasi yang tidak kompatibel (CSB/Cib5) pada berat molekul sekitar 21 dan $30 \mathrm{kDa}$ karena diduga adanya hambatan translokasi nutrisi dan air dari bawah ke atas atau translokasi asimilat dari atas ke bawah. Terjadinya hambatan translokasi tersebut diduga pula karena jaringan parenkima terbentuk secara berlebihan pada daerah pertautan, sehingga hubungan vaskular dan translokasi hara, air dan asimilat antara batang bawah dan batang atas terhambat.

Hal tersebut menyebabkan pertumbuhan dan perkembangan planlet menjadi terganggu, atau terbentuk sambungan yang tidak harmonis sehingga aktivitas enzim tertentu meningkat yang dapat menghambat translokasi dan senyawasenyawa tertentu yang melintasi daerah 
Kompatibilitas sambung mikro Cinchona ledgeriana dengan C. succirubra berdasarkan...
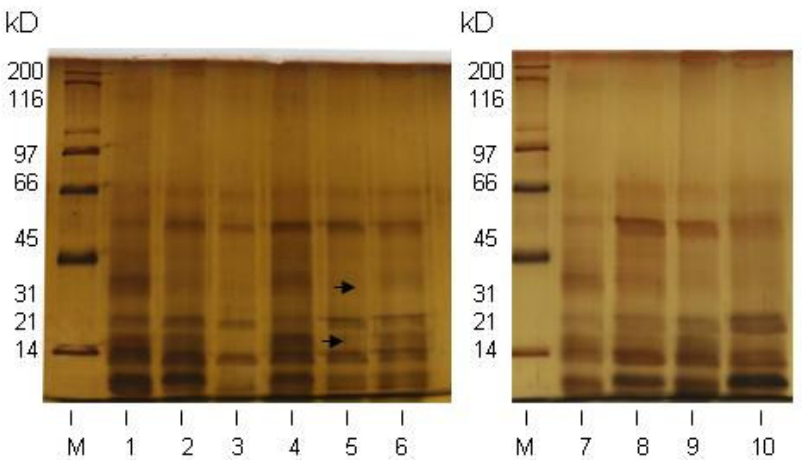

Gambar 5. Elektroforesis protein daun batang atas planlet kina hasil sambung mikro in vitro. M. Marker; 1.Cib5; 2. QRC205; 3. CSA/QRC205; 4. CSA/Cib5; 5. CSB/Cib5; 6.CSB/QRC205; 7. CSA/CSA; 8. CSB/CSB; 9. QRC205/QRC205; 10. Cib5/Cib5.

Figure 5. Protein electrophoresis of scion leaves of cinchona from micrografted. M. Marker 1.Cib5; 2. $Q R C 205$; 3. $C S A / Q R C 205$; 4. CSA/Cib5; 5. CSB/Cib; 6.CSB/QRC205; 7. CSA/CSA; 8. $C S B / C S B$; 9. QRC205/QRC205; 10. Cib5/Cib5.

pertautan. Hasil yang diperoleh mendukung hasil analisis anatomi daerah pertautan, yaitu kombinasi CSB/Cib5 memperlihatkan terbentuknya sel-sel baru pada daerah pertautan. Di samping itu terbentuk kalus yang berlebihan pada daerah pertautan sambungan yang tidak mulus (Gambar 3). Dari hasil percobaan juga menunjukkan bahwa pada kombinasi $\mathrm{CSB} / \mathrm{Cib5}$ pertumbuhan jumlah daun lebih rendah dari kombinasi lainnya.

Ji-Zhong et al. (2001) menyatakan pada penyambungan apel yang tidak kompatibel menyebabkan tingginya aktivitas enzim POD dan IOD dan dapat mendegradasi auksin yang ditranslokasikan dari pucuk ke akar. Holbrook et al. (2002) menyatakan bahwa pada kombinasi yang kompatibel terjadi hubungan yang positif antara batang bawah dengan batang atas sehingga proses distribusi hara, kemampuan hara bergerak melintasi bagian penyambungan, dan regulasi transpor hormon berlangsung dengan baik. Raghothama (1999) menyatakan bahwa pada penyambungan Arabidopsis yang kompatibel hubungan timbal balik (source dan sink) antara batang bawah dan batang atas terjadi secara normal.

Monero et al. (1994) menemukan pada penyambungan planlet peach dengan plum yang tidak kompatibel menyebabkan penurunan kandungan protein dan asam amino di seluruh organ planlet. Adanya degradasi pita protein terhadap kombinasi yang diuji diduga karena adanya hambatan translokasi berbagai senyawa yang diperlukan planlet dalam proses metabolisme pada kombinasi yang tidak kompatibel. Bertrand \& Etienne (2001) menyatakan bahwa tidak munculnya pola pita protein tertentu karena terganggunya proses metabolisme atau hambatan dalam proses translokasi berbagai senyawa yang diperlukan planlet. Toruan-Mathius et al. (1999, 2000 \& 
Toruan-Mathius et al.

2002) menyatakan bahwa terjadinya variasi pola pita protein dan isoenzim esterase dan peroksidase pada penyambungan tanaman karet karena interaksi yang berbeda terhadap masing-masing kombinasi batang bawah dan batang atas.

Berdasarkan ada dan tidaknya pola pita protein yang muncul pada planlet hasil mikrografting dapat disimpulkan bahwa protein merupakan salah satu indikasi pada fase dini terhadap kombinasi yang kompatibel dengan kombinasi yang tidak kompatibel dalam mikrografting. Errea et al. (2001) menyatakan bahwa teknik mikrografting dapat digunakan untuk mendeteksi secara dini kombinasi penyambungan batang bawah dan batang atas yang kompatibel maupun kombinasi yang tidak kompatibel.

Lizawati et al. (2002) melaporkan bahwa adanya pengaruh batang bawah tanaman karet klon RRC110 dapat mendegradasikan beberapa pita protein lateks batang atas klon RRIC100. Menurut Turnbull et al. (2002) pada batang bawah yang tidak kompatibel terhadap batang atas, terjadi pengiriman sinyal ke batang atas yang mirip dengan sinyal tanaman terhadap cekaman lingkungan.

\section{Kesimpulan}

1. Pada kombinasi mikrografting yang kompatibel CSA/QRC205 menunjukkan struktur anatomi daerah pertautan yang sama dengan struktur anatomi batang individu batang yang tidak disambung. Sedangkan kombinasi mikrografting yang tidak kompatibel CSB/Cib5, pada daerah pertautan terbentuk lapisan nekrotik yang memanjang hampir memotong bagian tengah batang.
2. Tahapan pemulihan daerah pertautan penyambungan batang bawah dengan batang atas diawali dengan pembentukan kalus, diferensiasi sel dan terbentuknya jaringan ikatan pembuluh gabungan.

3. Pada kombinasi yang kompatibel, pola pita protein yang muncul sama dengan planlet yang tidak disambung sedangkan pada kombinasi yang tidak kompatibel pola pita protein berbeda dengan pola pita protein planlet kontrol yaitu terjadi degradasi dua pita protein pada berat molekul sekitar 21 dan $30 \mathrm{kD}$.

\section{Ucapan Terima Kasih}

Penulis mengucapkan terima kasih kepada Kepala Balai Penelitian Bioteknologi Perkebunan Indonesia, Bogor atas fasilitas penelitian dan Direktur Pusat Penelitian Teh dan Kina, Gambung atas izin menggunakan bahan tanam kina yang digunakan dalam penelitian ini.

\section{Daftar Pustaka}

Agbaria, H., B.Heuer \& N. Zieslin (1997). Rootstock-imposed formation of protein in leave of rose (Rosa hybrida cv Mercedes). Adv. Hort. Sci., 11, 159-160.

Agbaria, H., B.Heuer \& N. Zieslin (1998). Rootstock-imposed alterations in nitrate reductase and glutamine synthetase activities in leaves for rose plant. Biol. Plant., 41 (1), 85-101.

Bertrand, B. \& H. Etienne (2001). Growth, production, and bean quality of Coffea Arabica as affected by interspecific grafting: Consequences for rootstock breeding. J. Hort. Sci., 36 , $269-273$. 
Kompatibilitas sambung mikro Cinchona ledgeriana dengan C. succirubra berdasarkan...

Errea, P., L. Garay \& A.J. Marin (2001). Early detection of graft incompatibility in apricot (Prunus armeniaca) using in vitro techniques. Physiol. Plant., 112, 135-141.

Estrada-Luna, A, A., C. Lopez-Peralpa \& E. Cardenas-Soriano (2002). In vitro micrografting and the histology of graft union formation of selected species of prikly pear cactus (Opuntia spp.). Sci. Hort., 92, 317-327.

Hartmann, H.T., D.E. Kester \& F.T Davies (1997). Plant Propagation, Principles and Practice. Sixth Edition. New Jersey, Practice Hall International Inc. $770 \mathrm{p}$.

Holbrook, N.M., V.R. Shashidhar, R.A. James \& R. Munns (2002). Stomatal control in tomato with ABA-deficient roots: response of grafted plants to soil drying. J. Exp. Bot., 53, 1503-1514.

Ji-Zhong, Xu., Shi Bao-Sheng, MA Bao-kun, Guo Run-Fang, Li Xiao-Dong \& Zhang Xian-Bin (2002). Studies on the POD and IOD activities of the dwarfing stocks and the red fuji apple grafted on corresponding interstocks. China. Agric. Sci., 1 (5), 562-567.

Lasminingsih, M., A. Hartana \& D. Fardiaz (1989). Pola pita protein beberapa klon karet Buletin Perkebunan Rakyat, 5, 34 38.

Leammli, U.K. (1970). Cleavage of structural protein during the assembly of the heat of bacteriophag T4. Nature, 227, 680-685.

Lizawati (2002). Analisis interaksi batang bawah dan batang atas pada okulasi tanaman karet. Tesis Bogor, Sekolah Pascasarjana, Institut Pertanian Bogor.

Lowry, O.H., F.A.L. Rosebrough \& R.J. Randal (1951). Protein measurement with the folin phenolreagent. J. Biol. Chem., 193-205.
Madjid, A. (1974). Bahan tanaman karet untuk peremajaan. Menara perkebunan, 42(5), 267-269.

Monero, M.A., J.P. Gaidillere \& A. Moing (1994). Protein and amino accid content in compatible and incompatible peach/ plum grafts. J Hort. Sci., 115 (2), 312319.

Murashige, T \& F. Skoog (1962). A revised medium for rapid growth and bioassay with tobacco tissue culture. Physiol. Plant., 15, 473-497.

Prawoto, A.A., W. Soerodikoesoemo \& J. Isbandi (1987). Kajian okulasi pada tanaman kakao (Theobroma cacao L) III. Anatomi pertautan batang bawah dan batang atas. Pelita Perkebunan, 6(2), 1330 .

Raghothama, K.G. (1999). Phosphate acquisition. Ann. Rev. Plant Physiol. Plant Mol. Biol., 50, 665-693.

Richardson, F. V. M., S. M.Tsaoir \& B.M.R. Harvey (1996). A study of the graft union in vitro micrografted apple. Plant Growth Regul., 20, 17-23.

Rifa'i-Faiz (2003). Pengaruh batang bawah dan jenis bibit serta studi anatomi bidang penyambungan pada bibit grafting duku (Lansium domesticum Corr). Skripsi Bogor, Jurusan Budidaya, Fakultas Pertanian, Institut Pertanian Bogor.

Sobhana, P., J. Gopalakrishan, J. Jacob \& M.R.Sethuraj (2001). Physiological and biochemical aspects of stock-scion interaction in Hevea brasiliensis. Indian J. Nat. Rub. Res., 14(2), 131-136.

Tirtawinata, M.R. (2003). Kajian anatomi dan fisiologi sambung bibit manggis dengan beberapa anggota kerabat Clusiaceae. Disertasi. Bogor, Sekolah Pasasarjana, Institut Pertanian Bogor.

Toruan-Mathius, N., S.A. Adimihadja \& I. Boerhendhy (1999). Rootstock-Scion 
Toruan-Mathius et al.

interaction in Havea : Bark protein patterns and anatomy in correlation with genetic similarities. Menara Perkebunan 67(1), 1-2.

Toruan-Mathius, N., I. Boerhendhy, MadjidAkbar \& Kuswanhadi (2000). Rootstockscion interaction induced the alteration of protein banding patterns of scion, and its correlation with genetic similarities in Hevea brasiliensis Muell Agr. In Proc. Indonesian Rubb. Conf. \& IRRDB Symposium. Bogor, 12-14 September 2000, volume I p. 169-179.

Toruan-Mathius, N., Lizawati, H. Aswidinnoor \& I. Boerhendhy (2002). Pengaruh batang bawah terhadap pola pita isoenzim dan protein batang atas pada okulasi tanaman karet (Hevea brasiliensis Muell Agr.). Menara Perkebunan, 70 (1), 20-34.

Turnbull, C. G. N., J. P. Booker \& H. M. O Leyser (2002). Micrografting techniques for testing long-distance signalling in Arabidopsis. The Plant J., 32, 255-262.

Warmund, M.R., B.H Barritt, J.M. Brown, K.L. Schaffer \& B.R. Jeong (1993). Detection of vascular discontinuity in bud union of 'Jonagold' apple on mark rootstock with magnetic resonance imaging. J. Amer. Soc. Hort. Sci., 118, 92-96.

Xi, R.T. \& P.H. Ding (1993). A study on the uniting proccess of walnut grafting and the factors affecting. Acta. Hort., 311, 160-170. 